\title{
Foreign Entry Mode, Cultural Distance and Subsidiary Performance of
}

\author{
Malaysian Mnes \\ Dullah Mulok \\ School of Business and Economics, University Malaysia Sabah \\ 88999 Kota Kinabalu, Sabah, Malaysia \\ Tel: 60-88-320-000 Ext. 1613 E-mail: dhm@ums.edu.my \\ Raja Azimah Raja Omar Ainuddin \\ School of Business and Economics, Universiti Malaysia Sabah \\ 88999 Kota Kinabalu, Sabah, Malaysia \\ Tel: 60-88-320-000 Ext. 1710 E-mail: r_azimah@ums.edu.my
}

\begin{abstract}
This paper explores the extent to which foreign entry mode and cultural distance influence the performance of Malaysian Multinational Enterprise (MNE) subsidiaries established in foreign countries. Data for this study were obtained from 13 Malaysian MNEs, which provided information on a total of 26 subsidiaries located in 16 countries. Implications of the study findings are discussed and suggestions for future research are provided.
\end{abstract}

Keywords: Foreign entry mode, Cultural distance, Foreign subsidiary performance, Malaysia

\section{Introduction}

Increased globalization and liberalization of economies in recent years have forced Malaysian companies to seek new locations for cheaper resources and new markets. As a latecomer in the global competitive arena, the Malaysian Multinational Enterprises (MNEs) lack international experience, knowledge and resources to compete with giant Multinational Companies (MNCs) from the more developed countries. Thus, foreign direct investments undertaken by the Malaysian MNEs faces greater challenges to compete in their new foreign locations.

Previous literatures on international expansion have focused mainly on MNCs from developed countries particularly, US and Europe (Stopford \& Wells, 1972). Nevertheless, by the end of the 1970s and 1980s, studies started to focus on MNEs from Japan (Kimura, 1989) and on MNEs from developing countries such as India, Hong Kong, Taiwan and the ASEAN countries (Wells, 1983; Kumar \& McLeod, 1981; Yeung, 1996). A study by Ragayah (1999) on Malaysian MNEs showed an increasing trend in the number of Malaysian companies starting operations in foreign countries. Internationalization strategies of MNEs from developing countries and emerging economies continue to be a major interest among international business researchers. While some aspects of their strategies are similar to their counterparts in the West and developed nations, differences can be seen as noted by Sim and Pandian (2003) in the internationalization strategies of MNEs from Taiwan and Singapore.

Reports on the performance of Malaysian MNEs in foreign countries have been based mostly on anecdotal evidence. A study has yet to be undertaken to determine their performance and the influence of equity-based entry modes and cultural differences on subsidiary performance. Although many literatures on foreign entry mode, cultural distance, and the effects of these factors on subsidiary performance but similar studies involving MNEs from developing and Asian countries are still very limited. These MNEs differ from those from developed countries in terms of their international knowledge and experience and they have very limited resources in terms of managerial expertise and firm specific assets. In light of these disadvantages and relatively higher risks, it would be interesting to note how they perform in foreign locations.

In this study, we extend the study by Ragayah (1999) by investigating the performance of Malaysian subsidiaries overseas. Two factors commonly related to performance, namely entry mode and cultural distance will be examined.

\section{Literature Review and Hypotheses}

This section reviews existing literature on foreign entry mode, cultural distance and performance of the MNEs' foreign subsidiaries. Hypotheses showing relationships between these variables are developed. 


\subsection{Foreign Entry Mode}

Previous studies have shown that there are at least three forms of equity-based foreign entry modes - greenfield wholly-owned subsidiaries, joint ventures and acquisitions (Nitsch, Beamish \& Makino, 1996). Greenfield wholly-owned subsidiaries involve the formation of a new company by the MNE and holds at least $80 \%$ ownership of the company (Yiu \& Makino, 2002). Joint ventures are subsidiaries that involve shared ownership between the MNE and a local company of a foreign country in which the subsidiaries are established. In joint ventures, at least $20 \%$ ownership of the subsidiary is held by either the MNE or the local partner (Makino \& Beamish, 1998). Acquisitions are local companies that were purchased by the MNE either for full ownership to form wholly-owned subsidiaries or partial ownership to form joint ventures.

\subsection{Entry Mode and Performance}

Previous studies have shown that a relationship exists between entry mode and firm performance. A study on Japanese Foreign Direct Investment (FDI) in Western Europe by Nitsch, Beamish \& Makino (1996) showed that wholly owned subsidiaries performed better than joint ventures. Similarly, Japanese FDI in the US that formed new wholly-owned subsidiaries showed better performance than joint venture subsidiaries (Woodcock, Beamish \& Makino, 1994).

Hence, based on previous studies, the following hypothesis is proposed:

H1: Wholly owned foreign subsidiaries of Malaysian MNEs are more likely to perform better than joint venture subsidiaries.

\subsection{National Cultural Distance}

National cultural distance is the difference between the culture of the parent company's country and the culture of the host country in which the subsidiary company is located. Based on Hofstede's four cultural dimensions, namely; power distance, individualism-collectivism, uncertainty avoidance and masculinity-femininity, the cultural distance is calculated using Kogut \& Singh's (1989) formula:

$$
C D_{j}=\sum\left\{\left(I_{i j}-I_{i u}\right)^{2} / V_{i}\right\} / 4
$$

where

Iij is the index for the $i t h$ cultural dimension and $j$ th country,

$V i$ is the variance of the index of the ith dimension,

$u$ indicates the United States (in this study, Malaysia), and

$C D j$ is cultural difference of the $j$ th country from the United States (in this study, Malaysia).

\subsection{Foreign Entry Mode and Cultural Distance}

Previous studies on the relationship between entry mode and cultural distance showed inconclusive findings. Some studies suggested that high cultural distance tend to be associated with the formation of wholly-owned subsidiaries (Anand \& Delios, 1997; Padmanabhan \& Cho, 1996; Sim \& Pandian, 2003). Some studies found no relationship between entry mode and cultural distance (Erramilli, 1996; Gatignon \& Anderson, 1988; Rajan \& Pangakar, 2000). A relatively larger number of studies showed the formation of joint ventures in countries exhibiting large cultural distance (Brouthers \& Brouthers, 2001; Kogut \& Singh, 1988; Erramilli \& Rao, 1993; Kim \& Hwang, 1992). Large cultural distance indicates greater uncertainty thus higher costs in terms of administrative costs. In joint ventures costs can be shared with the partner and such costs may be reduced with the help of the local partner (Brouthers \& Brouthers, 2001; Kogut \& Singh, 1988).

Based on the findings of previous studies and the argument that larger cultural distance indicates greater uncertainty and that uncertainty can be reduced, by taking a partner, the following hypothesis is proposed for this study:

H2: MNEs are more likely to form joint ventures in countries that exhibit high cultural distance and choose to form wholly owned subsidiaries in countries that exhibit low cultural distance.

\subsection{Foreign Entry Mode, Cultural Distance and Subsidiary Performance}

Previous studies have not analyzed the relationships between entry mode, cultural distance and firm performance simultaneously. Thus in this study, an attempt is made to assess the influence of both entry mode and cultural distance on performance by presenting the following hypotheses:

H3a: Subsidiary performance is higher in wholly owned subsidiaries than in joint ventures that are formed in low cultural distance countries.

H3b: Subsidiary performance is higher in joint ventures than in wholly owned subsidiaries that are formed in high cultural distance countries. 


\section{Methodology}

This study was based on a convenient sample of 13 MNEs which have a total of 26 operations in a total of 16 countries. Malaysian companies that have operations in other countries were identified from the list of public companies listed in the Kuala Lumpur Stock Exchange (KLSE). Based on information provided in the KLSE Handbook 2001, 113 companies listed as having set up operations in at least one foreign country. These companies were contacted to solicit their cooperation by participating in this study. Only thirteen companies indicated their willingness to participate after they were approached by personal contacts of the researcher.

A survey questionnaire was designed for the study aimed specifically for respondents who were CEOs, Managing Directors or General Managers of the sample companies. Questions pertaining to foreign entry mode, profile of the Malaysian parent company and performance of their foreign subsidiaries were included.

On foreign entry mode, respondents were asked the mode of foreign entry in terms of equity-based ownership; that is whether the foreign subsidiary was a wholly-owned subsidiary of the Malaysian parent or a joint venture with a foreign partner located in the host country. Questions of performance relate to the perceptions of the respondents with regards to the levels of profitability using the following scale: ' -2 ' = 'Very unprofitable', '-1' = 'Unprofitable', ' 0 ' = Neutral', $' 1$ ' = Profitable and ' 2 ' = Very profitable. Due to the small sample size, only mean scores and percentages are presented.

\section{Results and Discussion}

In this section, a profile of the Malaysian MNEs is presented followed by an exploratory analysis of the hypotheses.

\section{Profile of Malaysian MNEs}

The location of Malaysian MNEs in the following sample report indicates having subsidiaries in a number of countries, represented in four continents (Table 1).

In Asia, Malaysian MNEs have formed subsidiaries in Indonesia, Singapore, Thailand, Vietnam, China, Pakistan, Sri Lanka and the United Arab Emirates. In Europe, subsidiaries of Malaysian MNEs can be found in Denmark, Germany, Italy and the UK. In North America, subsidiaries were established in the USA, Canada and Mexico. A Malaysian MNE subsidiary in this study sample was also identified in Australia.

Out of the 13 Malaysian MNEs in this sample, five MNEs (35.5\%) reported as having only one foreign subsidiary, three MNEs (23\%) reported as having two foreign subsidiaries and another five MNEs (35.5\%) reported as having set up three subsidiaries overseas.

In terms of ownership, out of a total of 26 foreign subsidiaries in this study sample, 14 companies were wholly owned and 12 others were joint ventures (Table 2). For joint venture type subsidiaries, three were majority-owned by the Malaysian MNE and nine subsidiaries were minority-owned by the Malaysian parent.

The Malaysian MNEs report operations covering to several industries: three in chemical, four in palm oil and one each in food, signage, textile, plastic, crane, electric and electronic and real estate (Table 3). It is interesting to note that subsidiaries set up in foreign countries were operating in the same industry as their respective parents. This indicates that the MNE engaged in geographic diversification by leveraging their assets and capabilities overseas do compete in the same industry.

Table 4 shows the performance of Malaysian MNE subsidiaries. Based on perceptions of the respondents on the level of profitability of their foreign subsidiaries abroad, 19 subsidiaries (73\%) indicated that their foreign ventures were profitable, 4 subsidiares (15\%) indicated not profitable and 3 subsidiaries (12\%) gave a neutral response.

\subsection{Foreign Entry Mode and Performance}

The study results show that the mean performance of wholly owned subsidiaries is $0.93(\mathrm{n}=14)$ and the mean performance for joint ventures is $0.92(\mathrm{n}=12)$. The difference in performance between wholly owned subsidiaries and joint ventures is not significant for this sample. Thus there seems to be no evidence from this study sample that wholly owned subsidiaries perform better than joint ventures. Hypothesis H1 which suggests that wholly-owned subsidiaries are more likely to perform better than joint venture subsidiaries is not supported in this study.

\subsection{Foreign Entry Mode and Cultural Distance}

Table 5 shows the number of subsidiaries formed by MNEs in the study sample according to mode of entry and cultural distance $(\mathrm{CD})$.

The results show that in low cultural distance countries, there is no difference in the number of joint ventures and wholly owned subsidiaries being formed. However, in high cultural distance countries, there seems to be a tendency for a relatively larger number of wholly owned subsidiaries than joint ventures. Thus, hypothesis $\mathrm{H} 2$ which suggests that 
MNEs tend to form joint ventures in high cultural distance countries and wholly owned subsidiaries in low cultural distance countries is not supported in this study.

\subsection{Cultural Distance and Performance}

The results in Table 6 show that performance of subsidiaries located in countries that exhibit similar cultures tend be higher than subsidiaries located in less culturally-similar countries.

\subsection{Foreign Entry Mode, Cultural Distance and Performance}

Taking into consideration both cultural distance and entry mode factors, Table 7 shows that when cultural distance is low, performance is higher among the wholly-owned subsidiaries compared to equity joint ventures. However, when cultural distance is high, performance is higher among joint ventures than wholly-owned subsidiaries. Thus hypotheses $\mathrm{H} 3 \mathrm{a}$ and $\mathrm{H} 3 \mathrm{~b}$ are supported.

The results suggest that Malaysian MNEs should form wholly-owned subsidiaries when entering culturally-similar countries and form joint ventures when entering less culturally-similar countries. In practice however, MNEs from developing countries like Malaysia may find that it is not easy to form joint ventures in developed countries. Unlike MNCs in developed countries, MNEs from developing countries do not possess firm specific assets needed by the host country firms. This finding is similar to a study by Sim and Pandian (2003) who found that Taiwanese and Singaporean MNEs formed wholly-owned subsidiaries when investing in high cultural distance countries like Mexico, US and Europe.

Also in practice, MNEs from Malaysia will find it difficult to form wholly-owned subsidiaries in culturally-similar countries as hypothesized. Like most developing countries, these culturally-similar countries like China, Indonesia, Vietnam, and Pakistan impose equity restrictions requiring foreign MNEs to form joint ventures with local companies. The inconsistency between theoretical considerations, empirical findings and managerial practice suggesting a high subsidiary performance among Malaysian MNEs is not attainable based on the findings in this study on the mode-cultural distance-performance relationship. Therefore, Malaysian MNEs will have to focus on other variables that influence performance as alternatives to overcome the constraints imposed by the choice of entry mode.

\section{Conclusion}

The findings of previous studies have shown the importance of choosing the appropriate mode when investing in foreign countries. As shown by empirical findings, subsidiaries formed in low cultural distance countries should be in the form of wholly-owned subsidiaries if they want to achieve high performance. In high cultural distance countries, firms should form joint ventures if they want to achieve high performance.

In the context of Malaysian MNEs, investing in low cultural distance countries are by coincidence developing countries in which the governments of these countries impose regulations on equity ownership (Gomes-Casseres, 1988), hence, the desired form of ownership, which is wholly-owned subsidiary is not attainable. When investing in high cultural distance countries, the joint venture is recommended. Unlike the large MNEs which possess firm specific assets that make them desirable partners, small MNEs will find it difficult to locate partners (in developed countries where cultural distance is high) when investing in developed countries. Hence, the desired mode is also not attainable.

While entry mode and cultural distance have been found to influence foreign subsidiary performance of MNCs from developed countries, these factors seem to be less appropriate in determining the performance of MNE foreign subsidiaries from developing countries like Malaysia.

Despite the constraints and study limitations (small sample size, lack of methodological rigor and exploratory in nature), the findings in this study can be used as a guide by managers and future researchers. For an extended future research, a large-scale study is needed to further verify the findings in this study. In addition, a review of the measures of cultural distance is needed to accurately determine what actually constitutes cultural distance.

\section{References}

Anand, J., and Delios, A. (1997). Modes of foreign entry: A transaction cost analysis and propositions. Journal of International Business Studies, 17: 1-26.

Brouthers, K.D., and Brouthers, L. E. (2001). Explaining the national cultural distance paradox. Journal of International Business Studies, 32(1): 177-189.

Erramilli, M. K. (1996). Nationality and subsidiary ownership patterns in multinational corporations. Journal of International Business Studies, 27(2): 225-248.

Erramilli,M. K., and Rao, C.P. (1993). Service firms' international entry-mode choice: A modified transaction-cost analysis approach. Journal of Marketing, 57(July): 19-38. 
Gatignon, H., and Anderson, E. (1988). The multinational corporation's degree of control over foreign subsidiaries: An empirical test of a transaction cost explanation. Journal of Law, Economics and Organization, 4: 305-336.

Gomes-Casseres, B. (1988). Ownership structures of foreign subsidiaries: Theory and evidence. Journal of Economic Behavior and Organization, 11: 1-26.

Hofstede, G. (1980). Culture's Consequences. New York: Sage Publications.

Hofstede, G., and Bond, M.H. (1988). The Confucius Connection: From cultural roots to economic growth. Organizational Dynamics, 16(4): 4-21.

Kim, W. C., and P. Hwang, P. (1992). Global strategy and multinationals' entry mode choice. Journal of International Business Studies, 23: 29-53.

Kimura, Y. (1989). Firm-specific strategic advantages and foreign direct investment behavior of firms: The case of Japanese semiconductor firms. Journal of International Business Studies, 2: 296-314.

Kogut, B., and Harbir Singh. (1988). The effect of national culture on the choice of entry mode. Journal of International Business Studies, 19(Fall): 411-430.

Kumar, K., and McLeod, M.G. (eds.). (1981). Multinationals from Developing Countries. Lexington, MA: D.C. Heath.

Makino, S., and Beamish, P.W. (1998). Performance and survival of joint ventures with non-conventional ownership structures. Journal of International Business Studies, 29(4): 797-818.

Nitsch, D., Beamish, P.W., and Makino, S. (1996). Entry mode and performance of Japanese FDI in Western Europe. Management International Review, 36(1).

Padmabhan, P., and Cho, K.R. (1996). Ownership strategy for a foreign affiliate: An empirical investigation of Japanese forms. Management International Review, 30(1): 25-44.

Ragayah M. Z. (1999). Malaysian reverse investments: Trends and strategies. Asia Pacific Journal of Management , 16(3): 469-496.

Rajan, K.S., and Pangarkar, N. (2000). Mode of entry choice: An empirical study of Singaporean multinationals. Asia Pacific Journal of Management, 17(1): 49.

Sim, A. B., and Pandian, R J. (2003). Emerging Asian MNEs and their internationalization strategies - Case study evidence on Taiwanese and Singaporean firms. Asia Pacific Journal of Management, 20(1): 27.

Stopford, J. M., and Wells, L.T. Jr. (1972). Managing the multinational enterprise. New York: Basic Books.

Wells, L. T. (1983). Third World Multinationals. Cambridge, MA: MIT Press.

Woodcock, C.P., Beamish, P.W., and Makino. S. (1994). Ownership-based entry mode strategies and international performance. Journal of International Business Studies, 2: 253-273.

Yeung, W-C. H. (1994). Transnational corporations from Asian developing countries: Their characteristics and competitive edge. Journal of Asian Business, 10: 17-58.

Yiu, D and Makino, S. (2002). The choice between joint venture and wholly owned subsidiary: An institutional perspective. Organization Science, 13(6): 667-684. 
Table 1. Location of Malaysian MNE subsidiaries by region

\begin{tabular}{|c|c|}
\hline Region & Country \\
\hline Asia - South-east Asia & Indonesia (1) \\
\hline & Singapore (3) \\
\hline & Thailand (2) \\
\hline Asia - Outside South-east Asia & Vietnam (1) \\
\hline & Pakistan (2) \\
\hline Europe & Sri Lanka (2) \\
\hline & United Arab Emirates (1) \\
\hline & Denmark (1) \\
\hline North America & Germany (1) \\
\hline & Italy (1) \\
\hline & UK (1) \\
\hline & Canada (1) \\
\hline & Mexico (1) \\
\hline & USA (4) \\
\hline
\end{tabular}

( ) Numbers in brackets show number of subsidiaries

Table 2. Number of subsidiaries by mode of entry

\begin{tabular}{|c|c|}
\hline Ownership type & Number of subsidiaries \\
\hline Wholly-owned & 14 \\
\hline Majority-ownership & 3 \\
\hline Minority-ownership & 9 \\
\hline Total & 26 \\
\hline
\end{tabular}

Table 3. Comparing subsidiary industry and industry of MNE by order of entry

\begin{tabular}{|c|c|c|c|}
\hline Industry of MNE & $\begin{array}{l}\text { Subsidiary industry in } \\
\text { country } 1\end{array}$ & $\begin{array}{l}\text { Subsidiary industry in } \\
\text { country } 2\end{array}$ & $\begin{array}{l}\text { Subsidiary industry in } \\
\text { country } 3\end{array}$ \\
\hline Chemical & Chemical (Singapore) & Chemical (Indonesia) & \\
\hline Chemical & Chemical (USA) & Chemical (Canada) & Chemical (Singapore) \\
\hline Chemical & Chemical (China) & Chemical (UAE) & Chemical (USA) \\
\hline Palm oil & Palm oil (Pakistan) & & \\
\hline Palm oil & Palm oil (Germany) & Palm oil (Mexico) & Palm oil (Italy) \\
\hline Palm oil & Palm oil (Pakistan) & Palm oil (Sri Lanka) & \\
\hline Food & Food (Vietnam) & Food (Vietnam) & \\
\hline Signage & Signage (China) & & \\
\hline Textiles & Textiles (Sri Lanka) & & \\
\hline Plastics & Plastics (Thailand) & Plastics (UK) & Plastics (USA) \\
\hline Crane & Crane (Australia) & Crane (Denmark) & Crane (USA) \\
\hline Electric \& Electronic & E \& E (Thailand) & & \\
\hline Real estate & Real estate (China) & & \\
\hline
\end{tabular}


Table 4. Foreign subsidiary performance

\begin{tabular}{|c|c|c|}
\hline Performance level & $\begin{array}{c}\text { Number of } \\
\text { subsidiaries }\end{array}$ & Percent \\
\hline Highly profitable & 8 & 31 \\
\hline Profitable & 11 & 42 \\
\hline Neutral & 3 & 12 \\
\hline Not profitable & 4 & 15 \\
\hline Highly not profitable & 0 & 0 \\
\hline Total & 26 & 100 \\
\hline
\end{tabular}

Table 5. Number of subsidiaries by mode type and cultural distance

\begin{tabular}{|l|l|l|}
\hline & \multicolumn{1}{|c|}{ Wholly owned subsidiaries } & \multicolumn{1}{|c|}{ Equity joint ventures } \\
\hline Low CD countries & $8(50 \%)$ & $8(50 \%)$ \\
\hline High CD countries & $6(60 \%)$ & $4(40 \%)$ \\
\hline
\end{tabular}

Table 6. Mean performance of Malaysian MNE subsidiaries by cultural distance

\begin{tabular}{|c|c|}
\hline Cultural distance & Firm performance \\
\hline Low & 1.06 \\
\hline High & 0.6 \\
\hline
\end{tabular}

Table 7. Subsidiary performance by foreign entry mode and cultural distance

\begin{tabular}{|c|c|c|}
\hline & Small cultural distance & Large cultural distance \\
\hline Equity joint ventures & 0.75 & 1.25 \\
\hline Wholly owned subsidiaries & 1.50 & 0.17 \\
\hline
\end{tabular}

